\title{
Effects of hydrokinesiotherapy in pain, trophism and muscle strength in a child with juvenile idiopathic arthritis. Case report
}

\author{
Efeitos da hidrocinesioterapia na dor, no trofismo e na força muscular de uma criança com \\ artrite idiopática juvenil. Relato de caso
}

Matheus Santos Gomes Jorge ${ }^{1}$, Sabrina Casarin Vogelmann², Lia Mara Wibelinger

DOI 10.5935/2595-0118.20190016

\section{ABSTRACT}

BACKGROUND AND OBJECTIVES: Juvenile idiopathic arthritis is a childhood rheumatic disease, which can interfere with the trophism and muscular strength of the individual due to persistent pain. Hydrokinesiotherapy may be an alternative in the management of this disease. The objective of this study was to verify the effects of hydrokinesiotherapy on pain, trophism and muscular strength of a child with juvenile rheumatoid arthritis. CASE REPORT: Female patient, 12 years old, diagnosed with juvenile rheumatoid arthritis one year ago. The pain was evaluated by the visual analog scale and the body pain map, the muscular trophism by the perimetry of the arms and thighs, and the muscular strength by isokinetic dynamometry at a speed of $240^{\circ}$. The hydrokinetic therapeutic intervention program (adaptation, warm up, mobility and flexibility, muscle strengthening, cardiorespiratory fitness, balance and proprioception, and relaxation) was carried from October to December 2017, once a week, for 1 hour, totaling 10 sessions. At the end, there was a decrease in pain by 2.7 points (moderate to mild), an increase in muscle trophism of the arms and right thigh in $1 \mathrm{~cm}$ and an increase in the torque peak (progress ranging from 12.3 to $37.9 \%$ ) and total work (progress ranging from 18.6 to $76.7 \%$ ) in all muscle groups analyzed in both knees.

CONCLUSION: The hydrokinetic therapeutic intervention plan shown to be an effective strategy to alleviate the pain and increase trophism and muscle strength of the individual with juvenile idiopathic arthritis.

\footnotetext{
Matheus Santos Gomes Jorge - (Dhttps://orcid.org/0000-0002-4989-0572;

Sabrina Casarin Vogelmann - (Dhttps://orcid.org/0000-0002-2460-8067;

Lia Mara Wibelinger - (Dhttps://orcid.org/0000-0002-7345-3946.
}

1. Universidade de Passo Fundo, Faculdade de Educaçáo Física e Fisioterapia, Programa de Pós-Graduaçáo em Envelhecimento Humano, Bolsista Prosuc/CAPES. Soledade, RS, Brasil. 2. Universidade de Passo Fundo, Faculdade de Educaçáo Física e Fisioterapia, Curso de Fisioterapia. Passo Fundo, RS, Brasil.

3. Universidade de Passo Fundo, Faculdade de Educação Física e Fisioterapia, Programa de Pós-Graduaçấo em Envelhecimento Humano, Curso de Fisioterapia. Passo Fundo, RS, Brasil.

Submitted in August 30, 2018.

Accepted for publication in December 20, 2018.

Conflict of interests: none - Sponsoring sources: none

Correspondence to:

Rua Rio de Janeiro, 797 - Ipiranga

99300-000 Soledade, RS, Brasil.

E-mail: mathjorge5@gmail.com

(C) Sociedade Brasileira para o Estudo da Dor
Keywords: Chronic pain, Hydrotherapy, Juvenile arthritis, Muscle strength, Musculoskeletal system, Physiotherapy.

\section{RESUMO}

JUSTIFICATIVA E OBJETIVOS: A artrite idiopática juvenil é uma doença reumática da infância, que pode interferir no trofismo e na força muscular do indivíduo, devido à dor persistente. A hidrocinesioterapia pode ser uma alternativa no manuseio dessa doença. O objetivo deste estudo foi verificar os efeitos da hidrocinesioterapia na dor, no trofismo e na força muscular de uma criança com artrite reumatoide juvenil.

RELATO DO CASO: Paciente do sexo feminino, 12 anos de idade, diagnosticada com artrite reumatoide juvenil há um ano. Avaliou-se a dor por meio da escala analógica visual e do mapa de dor corporal; o trofismo muscular, por meio da perimetria dos braços e das coxas; e a força muscular, por meio da dinamometria isocinética em velocidade de $240^{\circ}$. O programa de intervenção hidrocinesioterapêutica (adaptação, aquecimento, mobilidade e flexibilidade, fortalecimento muscular, condicionamento cardiorrespiratório, equilíbrio e propriocepçáo e relaxamento) foi realizado nos meses de outubro a dezembro de 2017 , uma vez por semana, durante 1 hora, totalizando 10 sessóes. Ao fim, houve diminuição da dor em 2,7 pontos (de moderada a leve), aumento do trofismo muscular dos braços e da coxa direita em $1 \mathrm{~cm}$ e aumento do pico de torque (progresso que variou entre 12,3 e 37,9\%) e do trabalho total (progresso que variou entre 18,6 e 76,7\%) em todos os grupos musculares analisados, de ambos os joelhos.

CONCLUSÁO: O plano de intervenção hidrocinesioterapêutica mostrou-se como uma estratégia eficaz para o alívio da dor e aumento do trofismo e da força muscular do indivíduo com artrite idiopática juvenil.

Descritores: Artrite juvenil, Dor crônica, Fisioterapia, Força muscular, Hidroterapia, Sistema musculoesquelético.

\section{INTRODUCTION}

Juvenile idiopathic arthritis (JIA) is a pediatric rheumatic disease characterized by persistent inflammation of the joints, with onset before the child reaches the age of 16 . The annual occurrence varies from 2 to 20 cases per 100,000 people, with a prevalence of 15 to 150 cases per 100,000 people $e^{1,2}$. Even though its etiology is as yet unknown, evidence points to genetic predisposition ${ }^{3}$.

The clinical conditions may include systematic manifestations, together with fever and inflammatory musculoskeletal bouts, including 
evidence of inflammation of the joints (pain, heat, redness, swelling, and loss of function), stiffness, cramp, tenosynovitis, contractures, atrophies, and muscular weakness, thereby leading to functional incapacity and general malaise ${ }^{3-5}$. As a rule, these patients also show dysfunctions and defects of the lower limbs ${ }^{2}$, especially on the knees, the ankles, the hips, and the minor joints of hands and feet 5 .

Approaches seeking the rehabilitation of children and teenagers with JIA have been exploited, but lack standardization in their protocols ${ }^{2}$. Hydrokinesiotherapy is considered one of the most promising interventions, bringing relief of pain, muscular relaxation, flexibility, and preservation or restoration of the functional capacity. The properties of water allow movement of the painful musculature, mobilizing and strengthening it through specific exercises ${ }^{3}$, being considered a safe strategy for this segment of the population ${ }^{6}$.

The purpose of this study was to check the effects of hydrokinesiotherapy on pain, trophism, and muscular strength, in a child with JIA.

\section{CASE REPORT}

This is a longitudinal and interventionist case report which is part of a project named "The Effects of Physiotherapeutic treatment in patients with rheumatic diseases. "The study was approved by the Research Ethics Committee for Research with Human Subjects, at the University of Passo Fundo, State of Rio Grande do Sul, Brazil, under protocol number 348,381, as established by resolution No. $466 / 2012$ passed by the Brazilian National Health Council (CNS) and the Helsinki Declaration.

The Free and Informed Consent Form (FICT) was signed by the girl's mother, after an explanation of the procedure and elucidation of any questions. Next, the participant was referred to the Rheumatology Physiotherapy Department of the Physiotherapy Clinic, which is part of the School of Physical Education and Physiotherapy of the University of Passo Fundo (UPF), in the city of Passo Fundo, State of Rio Grande do Sul, Brazil.

Female patient, aged 12, and diagnosed with JIA a year ago. She lived in the city of Passo Fundo, State of Rio Grande do Sul and was attending the $7^{\text {th }}$ year of primary education. At the initial evaluation, her mother reported that "the child started with fever, pain, and swelling in her joints, back in October 2016. At that time, she was hospitalized for five days and diagnosed with JIA. In May, she had a crisis and almost lost her ability to walk due to the pain and the swelling" (according to information collected). The child also complained of pain in her right foot, of the "pressing" type, with a score of 7 , which got worse during the night and then improved during movement (according to information collected). She was taking five different drugs of continuous use: Predsim; Methotrexate; folic acid; calcium; vitamin D; and Omeprazole'). She did not show any associated diseases, and neither any family history of rheumatic disease.

The pain was analyzed through the visual analog pain scale (VAS) and also through the map of body pain. The first consists of a horizontal straight line numbered from zero (no pain) to 10 (the worst pain you can imagine) $)^{7}$. The pain is classified as light (zero to 2 ), moderate (3 to 7 ) or intense (8 to 10 ).

The latter is an instrument that included a graphic representation of the human body from anterior and posterior view, where the patient identifies the points where he or she feels pain at the moment of the evaluation ${ }^{3,8}$.

Muscular trophism was evaluated through perimetry, a test which uses a measuring tape to establish the circumference of a specific body segment ${ }^{3}$. In the study, the muscular trophism in the arms (10 and $15 \mathrm{~cm}$ above the olecranon) and the thighs (10 and $15 \mathrm{~cm}$ above the center of the patella), standards mentioned in another study conducted on an individual with rheumatoid arthritis?

Muscular strength was analyzed by isokinetic dynamometry, using the Biodex ${ }^{\mathrm{TM}}$ Multi-Joint System 3 Pro computerized isokinetic dynamometer, which is considered to be the gold standard for evaluation of muscular strength ${ }^{3}$. Preliminary studies ${ }^{10,11}$ have shown that this equipment could even be used among the pediatric population, as it shows good reliability and can be easily applied for this procedure, with its limitations being easily overcome.

Initially, the child had a five-minute pre-warming up session on a Movement BM 2700 electromagnetic bicycle, with no load, and with the seat adjusted to the appropriate height for the child. Next, the child received information about the procedure that would be carried out. The dynamometer was moved along the horizontal plane and positioned on the external side of the unaffected lower limb. The accessory of the knee was then connected to the dynamometer, and the rotation axis of the subject's knee was brought into alignment with the axis of the dynamometer. The height of the seat was also adjusted, in the direction of the dynamometer. The patient was then stabilized by a pair of elbow belts, a pelvic belt, and a belt for the contralateral thigh. After the preparation, the child performed three movements of extension and bending of the knee, at the speed of $180^{\circ}$ to learn the test procedure. The action took place through a series of five movements of extension and bending of the knee, in a concentric way, always assessing the extensor and flexor muscles of the knee, considering the average peak torque (maximum strength) and the total value of isokinetic muscular work, at a speed of $240^{\circ}$. The procedure was repeated, on the other side.

After evaluations, the child was then subjected to 10 individual sessions of hydrokinesiotherapy of approximately one hour (10 weeks), from October to December 2017. The intervention took place in a therapeutic pool, heated to a temperature of $36^{\circ} \mathrm{C}$, based on referenced studies ${ }^{12,13}$, to produce effects on the situation of pain, trophism, and the muscular force of the individual. Table 1 shows the hydrokinesiotherapy schedule.

The patient was advised to exhale during muscular contraction, to better recruitment of muscle fibers, which improves the performance of the exercise. There was an interval of 30 seconds to one minute between the series or cycles, but the patient could interrupt the activity for a rest whenever needed, conduct adopted in a previous study ${ }^{14}$. After the 10 sessions of hydrokinesiotherapy, all parameters were reassessed. Table 2 shows the reference values for the child's pain, in phases before and after hydrokinesiotherapy.

There was a reduction of the score and the intensity of the pain, after the intervention. However, pain started to be reported in more than one place. Table 3 shows the reference values for the muscular trophism of the patient, before and after intervention with hydrokinesiotherapy. After the physiotherapy, the patient showed an increase of $1 \mathrm{~cm}$ in all measurements of muscle trophism of the arms, and $15 \mathrm{~cm}$ above the anatomical reference point of the right thigh, after the 
Table 1. Hydrokinesiotherapy schedule, Passo Fundo, Rio Grande do Sul, Brazil, 2018

\begin{tabular}{|c|c|c|}
\hline Phases & Exercises & Progression \\
\hline \multirow{2}{*}{$\begin{array}{l}\text { Phase } 1-\text { Adaptation } \\
\text { (from the } 1^{\text {st }} \text { to the } 3^{\text {rd }} \\
\text { session) }\end{array}$} & $\begin{array}{l}\text { Walking around the pool, facing forward, sideward and } \\
\text { backward. }\end{array}$ & 3 rounds, in each direction \\
\hline & $\begin{array}{l}\text { Diaphragmatic respiratory exercise, where the individual } \\
\text { should exhale under water. }\end{array}$ & 3 series with 5 repetitions each. \\
\hline \multirow[t]{2}{*}{ Phase 2 - Warming Up } & $\begin{array}{l}\text { Slow muscular stretching, maintained, in either an acti- } \\
\text { ve-assisted or passive mode, using the main muscular } \\
\text { groups of the upper limbs, lower limbs, and trunk. }\end{array}$ & 30 seconds for each muscle group \\
\hline & Circular movements of shoulders, neck, wrists, and ankles & 30 seconds for each joint \\
\hline \multirow[t]{3}{*}{$\begin{array}{l}\text { Phase } 3 \text { - Mobility and } \\
\text { Flexibility }\end{array}$} & Rotation of trunk with floaters around the arms & $\begin{array}{l}1^{\text {st }} \text { to } 5^{\text {th }} \text { session: } 2 \text { series with } 10 \text { repetitions each } \rightarrow 6^{\text {th }} \\
\text { to } 10^{\text {th }} \text { session: } 3 \text { series with } 8 \text { repetitions each }\end{array}$ \\
\hline & $\begin{array}{l}\text { Mobilization of wrists (active movements of flexion and } \\
\text { extension) with floaters }\end{array}$ & $\begin{array}{l}1^{\text {st }} \text { to } 5^{\text {th }} \text { session: } 2 \text { series with } 10 \text { repetitions each } \rightarrow 6^{\text {th }} \\
\text { p } 10^{\text {th }} \text { session: } 3 \text { series with } 8 \text { repetitions each }\end{array}$ \\
\hline & $\begin{array}{l}\text { Mobilization of ankles (movements of dorsiflexion and } \\
\text { plantar flexion) on a submerged step }\end{array}$ & $\begin{array}{l}1^{\text {st }} \text { to } 5^{\text {th }} \text { session: } 2 \text { series, with } 10 \text { repetitions each } \rightarrow \\
6 \text { th to } 10 \text { th session: } 3 \text { series with } 8 \text { repetitions each }\end{array}$ \\
\hline \multirow[t]{3}{*}{$\begin{array}{l}\text { Phase } 4-\text { Muscular } \\
\text { strengthening }\end{array}$} & $\begin{array}{l}\text { Strengthening of the hands (movements of manual } \\
\text { prehension and also finger tweezers) with a "mild" pro- } \\
\text { prioceptive ball ( } 1^{\text {st }} \text { to } 5^{\text {th }} \text { session) and "moderate" }\left(6^{\text {th }} \text { to }\right. \\
\text { 10th session) }\end{array}$ & $\begin{array}{l}1^{\text {st }} \text { to } 5^{\text {th }} \text { session: } 2 \text { series, with } 10 \text { repetitions each } \rightarrow \\
6 \text { th to } 10 \text { th session: } 3 \text { series with } 8 \text { repetitions }\end{array}$ \\
\hline & $\begin{array}{l}\text { Strengthening of the adductor and abductor muscles of } \\
\text { the elbows, with floaters }\end{array}$ & $\begin{array}{l}1^{\text {st }} \text { to } 5^{\text {th }} \text { session: } 2 \text { series, with } 10 \text { repetitions each } \rightarrow \\
6 \text { th to } 10 \text { th session: } 3 \text { series with } 8 \text { repetitions }\end{array}$ \\
\hline & $\begin{array}{l}\text { Minicrouches on bipedal support (1st to } 7 \text { th session) and } \\
\text { unipodal support (8th to 10th sessions) }\end{array}$ & $\begin{array}{l}1^{\text {st }} \text { to } 5^{\text {th }} \text { session: } 2 \text { series, with } 10 \text { repetitions each } \rightarrow \\
6 \text { th to } 10 \text { th session: } 3 \text { series with } 8 \text { repetitions }\end{array}$ \\
\hline \multirow[t]{3}{*}{$\begin{array}{l}\text { Phase } 5 \text { - Cardiac and } \\
\text { respiratory conditioning }\end{array}$} & Stationary running & $\begin{array}{l}\text { 1st to } 5 \text { th session: } 1 \text { series of } 60 \text { seconds } \rightarrow 6 \text { th to } 10 \text { th } \\
\text { session: } 2 \text { series of } 60 \text { seconds each }\end{array}$ \\
\hline & Side jumps along a length of 5 meters & $\begin{array}{l}1^{\text {st }} \text { to } 5^{\text {th }} \text { session: } 1 \text { series, with } 10 \text { repetitions } \rightarrow 6 \text { th to } \\
\text { 10th session: } 2 \text { series of } 8 \text { repetitions }\end{array}$ \\
\hline & Lateral jumping jacks & $\begin{array}{l}1^{\text {st }} \text { to } 5^{\text {th }} \text { session: } 1 \text { series, with } 10 \text { repetitions } \rightarrow 6^{\text {th }} \text { to } \\
10^{\text {th }} \text { session: } 2 \text { series of } 8 \text { repetitions }\end{array}$ \\
\hline \multirow[t]{2}{*}{$\begin{array}{l}\text { Phase } 6 \text { - Balance and } \\
\text { proprioception }\end{array}$} & Stationary bicycle with two floaters between the legs & $\begin{array}{l}1^{\text {st }} \text { to } 5^{\text {th }} \text { session: } 60 \text { seconds } \rightarrow 6^{\text {th }} \text { to } 10^{\text {th }} \text { session: } 2 \\
\text { series of } 8 \text { repetitions }\end{array}$ \\
\hline & $\begin{array}{l}\text { Lift the lower limb with a floater, under the foot, first with } \\
\text { the knee bent ( } 1^{\text {st }} \text { to } 7^{\text {th }} \text { session) and then progressing to } \\
\text { exercise with the knee outstretched ( } 8^{\text {th }} \text { to } 10^{\text {th }} \text { session) }\end{array}$ & $\begin{array}{l}1^{\text {st }} \text { to } 5^{\text {th }} \text { session: } 2 \text { series of } 10 \text { repetitions } \rightarrow 6 \text { th to } 10 \text { th } \\
\text { session: } 3 \text { series of } 8 \text { repetitions }\end{array}$ \\
\hline Phase 7 - Relaxation & $\begin{array}{l}\text { Massotherapy on the cervical region, joint mobilizations } \\
\text { on the ankle and the spine, and movements of the Watsu } \\
\text { Method3. }\end{array}$ & $\begin{array}{l}1^{\text {st }} \text { to } 5^{\text {th }} \text { session: } 15 \text { minutes } \rightarrow 6^{\text {th }} \text { to } 10^{\text {th }} \text { session: } 10 \\
\text { minutes }\end{array}$ \\
\hline
\end{tabular}

$\rightarrow=$ progression of the exercise.

Table 2. Pain experienced before and after the hydrokinesiotherapy. Passo Fundo, Rio Grande do Sul, Brazil, 2018

\begin{tabular}{lcc}
\hline Variables & Before intervention & After intervention \\
\hline Point score according to VAS & $5.0 \pm 2.86(0-8)$ points & $2.3 \pm 1.94(0-4)$ points \\
Intensity of pain & Moderate & Light \\
Location of pain & Metatarsi and phalanges of the right foot & Posterior region of the right and left ankles
\end{tabular}

Mean \pm standard deviation (minimum - maximum); VAS = visual analog scale.

Table 3. Muscular trophism of the patient, before and after hydrokinesiotherapy. Passo Fundo, Rio Grande do Sul, Brazil, 2018

\begin{tabular}{lllll} 
& \multicolumn{2}{l}{$10 \mathrm{~cm}$ above the center of the patella } & \multicolumn{2}{l}{$15 \mathrm{~cm}$ above center of the patella } \\
& Before intervention & After intervention & Before intervention & After intervention \\
\hline Right Arm & $24 \mathrm{~cm}$ & $25 \mathrm{~cm}$ & $26 \mathrm{~cm}$ & $27 \mathrm{~cm}$ \\
Left Arm & $24 \mathrm{~cm}$ & $25 \mathrm{~cm}$ & $26 \mathrm{~cm}$ & $27 \mathrm{~cm}$ \\
Right Thigh & $43 \mathrm{~cm}$ & $43 \mathrm{~cm}$ & $45 \mathrm{~cm}$ & $46 \mathrm{~cm}$ \\
Left Thigh & $44 \mathrm{~cm}$ & $42 \mathrm{~cm}$ & $48 \mathrm{~cm}$ & $46 \mathrm{~cm}$ \\
\hline
\end{tabular}

$\mathrm{cm}=$ centimetres; ${ }^{*}=$ dominant side; ${ }^{* *}=$ dominant and affected side. 
Table 4. Muscle strength of the patient's knees, before and after the hydrokinesiotherapy. Passo Fundo, Rio Grande do Sul, Brazil, 2018

\begin{tabular}{|c|c|c|c|c|}
\hline \multicolumn{5}{|c|}{ Peak of torque } \\
\hline Knee & Muscle Group & Before intervention & After intervention & Progress \\
\hline \multirow[t]{2}{*}{ Right* $^{*}$} & Extensor muscles & $62.6 \mathrm{~N} \mathrm{~m}$ & $70.3 \mathrm{~N} \mathrm{~m}$ & $12.3 \%$ \\
\hline & Flexor muscles & $23.8 \mathrm{~N} \mathrm{~m}$ & $32.8 \mathrm{~N} \mathrm{~m}$ & $37.9 \%$ \\
\hline \multirow[t]{2}{*}{ Left } & Extensor muscles & $58.9 \mathrm{~N} \mathrm{~m}$ & $70.4 \mathrm{~N} \mathrm{~m}$ & $19.4 \%$ \\
\hline & Flexor muscles & $22.9 \mathrm{~N} \mathrm{~m}$ & $25.8 \mathrm{~N} \mathrm{~m}$ & $12.7 \%$ \\
\hline \multicolumn{5}{|c|}{ Total Work } \\
\hline Knee & Muscle Group & Before intervention & After intervention & Progress \\
\hline \multirow[t]{2}{*}{ Right $^{\star}$} & Extensor muscles & $242.3 \mathrm{~J}$ & $287.4 \mathrm{~J}$ & $18.6 \%$ \\
\hline & Flexor muscles & $94.1 \mathrm{~J}$ & $132.4 \mathrm{~J}$ & $40.6 \%$ \\
\hline \multirow[t]{2}{*}{ Left } & Extensor muscles & $153.9 \mathrm{~J}$ & $272.0 \mathrm{~J}$ & $76.7 \%$ \\
\hline & Flexor muscles & $70.0 \mathrm{~J}$ & $101.5 \mathrm{~J}$ & $45.0 \%$ \\
\hline
\end{tabular}

$\mathrm{N} \mathrm{m}=$ Newton-metre; $\mathrm{J}=$ Joule; \% = relative value; * $=$ dominant and affected side.

hydrokinesiotherapy. Table 4 shows the values for muscle strength on the patient's knees, before and after the hydrokinesiotherapy.

We see that the patient showed an increase in muscle strength in all parameters analyzed, after hydrokinesiotherapy. With regards to the peak of torque, the flexor muscles of the right knee had the best performance, followed by the extensor muscles of the left knee, flexors of the left knee, and extensors of the right knee. Concerning total work, the extensor muscles of the left knee had the best performance, followed by the flexor muscles of the left knee, the flexors of the right knee, and the extensors of the right knee.

\section{DISCUSSION}

Children and adolescents with JIA show a reduction in muscle strength in the knees when compared to their peers who do not have the disease ${ }^{15}$. In addition, these people are also subject to biomechanical consequences on the joints, such as a higher risk of cartilage lesions ${ }^{16}$, as the muscles involved in this joint play a key role for stability and the prevention of lesions ${ }^{17}$.

The muscle weakness as shown may be related to arthritis (which causes constant pain) and muscle atrophy due to lack of use of the affected joint ${ }^{6}$. This was the situation observed in this specific case, where the muscle weakness present in the patient's clinical condition was accompanied by pain, and these conditions could also influence the patient's muscular trophism. In addition, we can say that there is a consensus among professionals specialized in pediatric rheumatology, that regular physical exercises are a safe approach. Physical exercises also promote the child's general skills and the normal development in early childhood, not to mention the handling of musculoskeletal symptoms, such as reduction in muscle force, physical resistance, and aerobic capacity ${ }^{18-20}$, with hydrokinesiotherapy being one of the main approaches used in rehabilitation in cases of JIA ${ }^{21}$. However, they also highlight that exercises on the floor bring better results in terms of muscle force, the execution of tasks, and functional state, compared with exercises in water ${ }^{18}$, which is largely due to the significant heterogeneity in the results of the studies already produced. These studies stress the need for standardized evaluation or a basic set of functional and physical measures well suited to research in the health field ${ }^{20}$.
The beneficial effects upon pain in the child with JIA also confirm the findings of other studies ${ }^{12,13}$ that use hydrokinesiotherapy as a plan for treatment of pain, observing a reduction among the individuals treated, stressing the use of strengthening exercises in their protocols, as adopted in this study.

Confirming the results presented in this study, the literature says that hydrokinesiotherapy does not influence muscle strength in people with lower limbs disorders, due to the inconsistent methodologies in most studies, especially those related to the prescription of resistance exercises in a water ${ }^{22}$.

The methodological design used in this study that analyzed the effects of hydrokinesiotherapy on muscle strength in a child with JIA by isokinetic dynamometer was observed in only one similar study. It was a study where 30 children with JIA were randomly distributed between a control group $(\mathrm{n}=15)$, subjected to conventional physiotherapy on the ground, and an intervention group $(n=15)$, which was subjected to a specific hydrokinesiotherapy programme for lower limbs ( 5 minutes warming up, then 20 minutes of resisted exercise, and 5 minutes of cooling off), associated with the interferential current in the muscles of the anterior, posterior, medial and lateral sections of the hips (frequency of $100 \mathrm{~Hz}$, pulse duration of $125 \mathrm{Ksec}$ at the sensorial threshold of the individual). After the intervention, the intervention group showed superior results when compared to the control group, regarding the increase in the peak torque of lower limbs and the reduction of the levels of pain ${ }^{23}$. In the present study, we confirmed that the plan for the hydrokinesiotherapy increased the peak of torque and also the total effort made by the extensor and flexor muscles of the knees, as well as easing the patient's intensity of pain, without the need for any additional resources.

The present report does have its limitations. Even though we have observed an improvement in muscle force and a reduction in pain intensity, we believe that the number and frequency of the sessions, which were lower than in most of the evidence presented in the literature, could have contributed to the fact that there was no evidence of an improvement in most measurements of muscle trophism of the patient's thighs. However, these circumstances did not hinder the generation of the data presented, seeking to contribute so that new studies are carried out, based on a more significant number of individuals, thereby allowing the solution of any questions that may have remained. 


\section{CONCLUSION}

The plan for intervention through hydrokinesiotherapy showed to be an effective strategy for pain relief and the increase of trophism and muscle strength in a patient with JIA.

\section{REFERENCES}

1. Thierry S, Fautrel B, Lemelle I, Guillemin F. Prevalence and incidence of juvenile idiopathic arthritis: a systematic review. Joint Bone Spine. 2014;81(2):112-7.

2. Fellas A, Coda A, Hawke F. Physical and mechanical therapies for lower-limb problems in juvenile idiopathic arthritis. A systematic review with meta-analysis. J Am Podiatr Med Assoc. 2017;107(5):399-412.

3. Wibelinger LM. Fisioterapia em Reumatologia. $2^{\text {a }}$ ed. Rio de Janeiro: Revinter; 2015.

4. Tugal-Tutkun I, Quartier P, Bodaghi B. Disease of the year: juvenile idiopathic arthritis-associated uveitis--classification and diagnostic approach. Ocul Immunol Inflamm. 2014;22(1):56-63.

5. Ravelli A, Martini A. Juvenile idiopathic arthritis. Lancet. 2007:369(9563):767-78.

6. Gualano B, Pinto AL, Perondi MB, Roschel H, Sallum AM, Hayashi AP, et al. [Therapeutic effects of exercise training in patients with pediatric rheumatic disease]. Rev Bras Reumatol. 2011;51(5):490-6. English, Portuguese.

7. Martinez JE, Grassi DC, Marques LG. [Analysis of the applicability of different pain questionnaires in three hospital settings: outpatient clinic, ward and emergency unit]. Rev Bras Reumatol. 2011;51(4):299-308. English, Portuguese.

8. Wenngren A, Stålnacke BM. Computerized assessment of pain drawing area: a pilot study. Neuropsychiatr Dis Treat. 2009;5:451-6.

9. Knob B, Jorge MS, Bresolin FL, Bolzan LA, Ribeiro DS, Zanin C, et al. Reabilitaçáo cinesioterapêutica em um homem com artrite reumatoide. Saúde Rev. 2017;17(46):35-45.

10. Tsiros MD, Grimshaw PN, Shield AJ, Buckley JD. The Biodex isokinetic dynamometer for knee strength assessment in children: advantages and limitations. Work. 2011;39(2):161-7.

11. Tsiros MD, Grimshaw PN, Schield AJ, Buckley JD. Test-retest reliability of the Biodex System 4 Isokinetic Dynamometer for knee strength assessment in paediatric populations. J Allied Health. 2011;40(3):115-9.

12. Félix TL, Jorge LM, Oliveira J, Mesquita-Ferrari RA. Efeito da hidroterapia, utilizando o Método dos Anéis de Bad Ragaz, no tratamento da artrite reumatóide juvenil: um estudo de caso. ConScientiae Saúde. 2007;6(2):341-50.

13. Santoni FC, Pereira de Freitas SC, Oliveira J, Mesquita RA. Hidroterapia e qualidade de vida de um portador de artrite reumatoide juvenil - estudo de caso. Fisioter Mov. 2007;20(1):101-8.

14. Jorge MS, Wibelinger LM, Knob B, Zanin C. Physiotherapeutic intervention on pain and quality of life of systemic sclerosis elderly patients. Case reports. Rev Dor. 2016;17(2):148-51.

15. Sandstedt E, Fasth A, Eek MN, Beckung E. Muscle strength, physical fitness and well-being in children and adolescents with juvenile idiopathic arthritis and the effect of an exercise programme: a randomized controlled trial. Pediatr Rheumatol Online J. 2013;11(1):1-7.

16. Myer GD, Brunner HI, Melson PG, Paterno MV, Ford KR, Hewett TE. Specialized neuromuscular training to improve neuromuscular function and biomechanics in a patient with quiescent juvenile rheumatoid arthritis. Phys Ther. 2005;85(8):791-802.

17. Batista JS, Martins AD, Wibelinger LM. Avaliaçáo da força muscular (torque muscular) de flexores e extensores de joelho de indivíduos jovens. EFDeportes. 2012;17(168):1-3

18. National Health and Medical Research Council. Clinical guideline for the diagnosis and management of juvenile idiopathic arthritis August 2009. Royal Australia College of General Practitioners. 2009. Available from: https://www.nhmrc.gov.au/_files_nhmrc/file/publications/synopses/cp119-juvenile-arthritis.pdf. Accessed June 13, 2018.

19. Baydogan SN, Tarakci E, Kasapcopur O. Effect of strengthening versus balance-proprioceptive exercises on lower extremity function in patients with juvenile idiopathic arthritis: a randomized, single-blind clinical trial. Am J Phys Med Rehabil. 2015;94(6):417-28.

20. Takken T, Van Brussel M, Engelbert RH, Van Der Net J, Kuis W, Helders PJ. Exercise therapy in juvenile idiopathic arthritis: a Cochrane Review. Eur J Phys Rehabil Med. 2008;44(3):287-97.

21. Cavallo S, Brosseau L, Toupin-April K, Wells GA, Smith CA, Pugh AG, et al. Ottawa Panel Evidence-Based Clinical Practice Guidelines for Structured Physical Activity in the Management of Juvenile Idiopathic Arthritis. Arch Phys Med Rehabil. 2017;98(5):1018-41.

22. Heywood S, McClelland J, Mentiplay B, Geigle P, Rahmann A, Clark R. Effectiveness of aquatic exercise in improving lower limb strength in musculoskeletal conditions: a systematic review and meta-analysis. Arch Phys Med Rehabil. 2017;98(1):173-86.

23. Elnaggar RK, Elshafey MA. Effects of combined resistive underwater exercises and interferential current therapy in patients with juvenile idiopathic arthritis. A randomized controlled trial. Am J Phys Med Rehabil. 2016;95(2):96-102. 